\title{
An Economic Study of the Marketing Efficiency for the Most Important Crops and Agricultural Commodities in Egypt
}

\author{
[Nouran Abd El Hamid Ibrahim Abd El Gawwad , Samir Basilious Nakhla Ghobrail, Mamdouh Elbadry Mohamed]
}

\begin{abstract}
This study aims to: estimate the marketing efficiency of the most important crops and agricultural commodities in Egypt represented in (wheat, maize, rice, lentils, faba bean, peanuts, tomatoes, onions, potatoes, zucchini, peas, garlic, cucumber, oranges, bananas, grapes, mangoes, dates, red meat, poultry, fish, oils) during the period (1998-2013) using the functions specified methodology of Farrell Approach, or Data Envelopment Analysis (DEA), according to the concepts of Constant Returns To Scale (CRS) ,Variable Returns To Scale (VRS) for estimating both the Technical Efficiency (TE), and Scale Efficiency (SE). It also aims to study the distribution of marketing margins and scale of marketing of the product, wholesaler and retailer of pounds consumer to know the factors that lead to the lifting of the marketing efficiency to achieve the objectives of both the producer and consumer.
\end{abstract}

It was found from the results of a study marketing efficiency by using Data Envelopment Analysis (DEA) in accordance with the model of Variable Return to Scale (VRS) for crops and commodities of this study, the average marketing efficiency amounted to about $85.7 \%$, 92.8\%, $90.4 \%, 83.7 \%, 77.1 \%$ for field crops, vegetable crops, fruit crops, meat, and oils, respectively.

While the average of Scale Efficiency reached about $83.5 \%, 88.1 \%, 83.9 \%, 74.4 \%, 93.5 \%$ for field crops, vegetable crops, fruit crops, meat, and oils, respectively. And suffer and commodities crops study of a lack of marketing efficiency was about $14.3 \%, 7.2 \%, 9.6 \%, 16.3 \%, 22.9 \%$ for field crops, vegetable crops, fruit crops

1- Authors Name/ Nouran Abd El hamid (Author) line1: Agricultural College / Mansoura University line2: Egypt

2- Authors Name/ Samir Basilious Nakhla (Author) line1: Institute of Agricultural Economic Research / Agricultural Research Center line2: Egypt

3- Authors Name/ Mamdouh Elbadry Mohamed (Author) line1: Institute of Agricultural Economic Research / Agricultural Research Center line2: Egypt
, meat, and oils, respectively, and this is due to other factors not included in the model, and thus marketing efficiency can be increased by reducing marketing margins used.

It turns out that about $71.9 \%, 63.4 \%, 66.3 \%, 89.6 \%$, $6.25 \%$ of the yield size in increasing returns to scale (irs) for field crops, vegetable crops, fruit crops, meat, oils, respectively. While it is showing that about $21.9 \%, 21.4 \%$, $16.3 \%, 4.2 \%, 87.5 \%$ of the yield size decreasing returns to scale (drs) for field crops, vegetable crops, fruit crops, meat, and oils, respectively.

Recommendations:

1. Working to improve marketing efficiency of agricultural products and commodities, as that would lead to improving the production efficiency of commodities and agricultural products, thereby increasing self-sufficiency ratios.

2. Through the use of a methodology (DEA) have been identified on the reasons for the lack of efficiency, and thus the possibility of working on the increase, and thus using the Envelopment data methodology when assessing marketing efficiency is preferred, because it is a scientific methodology utilized to know the reasons for the lack of efficiency, it can also find out crops and commodities the potential to increase efficiency, and the search for factors that help to do so.

3. Developing the production and marketing predictive policies for the most important crops and agricultural commodities, which benefit the product and trader of Egyptian crops and agricultural commodities.

4. The ability to make a national study on all the governorates of Egypt, leading to the identification of the causes of and obstacles to the lack of production and marketing efficiency of agricultural crops and commodities, and thus help develop plans to solve the problems and constraints of the lack of production and marketing efficiency of agricultural crops and commodities.

5. Marketing differences should be reduced through marketing tract of crops and agricultural commodities, where it was found that the marketing differences made by the intermediaries in the retail stage outweigh its counterpart in the wholesale stage.

6. Where crops are suffering most from the study and the lack of commodities in the marketing efficiency, and thus can increase marketing efficiency by reducing marketing margins.

7. Develop policies aimed at reducing the increase a marketing costs of the retail price, to reduce the increasing burden on the consumer in endures in the increasing share of marketing costs. 
Keywords-Deterministic Frontier Approach, Farrell Approach, (DEA) Data Envelopment Analysis , marketing , product's share, share of the wholesaler, , retailer, marketing , (CRS) Constant Returns to Scale, Variable Returns to Scale (VRS, Technical Efficiency (TE), Scale Efficiency (SE).

\section{Introduction}

Prices of agricultural commodities produced and marketed, and demand for the costs associated with, and the amount of expected revenue obtained from the sale, in addition to marketing services and quality of type, as well as affected by these prices the purchasing power of consumers and the type of market in terms of competition and monopoly. Efficiency performance marketing services through the stages of various marketing and urinary of the most important factors affecting the stability and expansion of productive in the production of these commodities, due interest in the study marketing margins for commodities and crops to it is considered the basis for the understanding of the marketing problems, and to judge the efficiency of the various processes in the course catalog, which absorbs a large part of every pound paid by the consumer, and on it The product's share of the price that consumers pay no more than half the consumer price, and this is a rise in marketing margins of the most important problems facing the marketing of these commodities. Identifying the most important marketing problems for producers of crops and agricultural commodities, and knowledge of the most important proposals and solutions necessary to lift the lead marketing efficiency and achieve the objectives of both the producer and the consumer.

The problem The study of marketing efficiency and marketing margins of the main crops and agricultural commodities of major importance in achieving marketing efficiency, and come to the short comings of the marketing process, affecting the marketing efficiency and lead to a lack of product for a price rewarding encourages him to continue in production, at the same time not to get consumer item required a fair price. And then it shall interest in the study of marketing efficiency of the most important agricultural crops, and work to improve it so that all of the product and the consumer benefit, as well as marketing devices for their services marketing, The problem of the study stand on the efficiency of the system marketing quo for the marketing of the most important crops and agricultural commodities in Egypt, and of the ( wheat, maize, rice, lentils, faba bean, peanuts, tomatoes, onions, potatoes, zucchini, peas, garlic, cucumber, oranges, bananas, grapes, mangoes, dates, red meat, poultry, fish, oils) so that it can the promotion of efficiency of marketing, where it was found to increase the prices of those crops and agricultural commodities , from 2008 to 2013 , an increase of about $37.8 \%, 105.9 \%, 64.2 \%$, $71.1 \%$, 20.4\%, respectively, for each of field crops, vegetables, fruit, meat, and oils, respectively, leading to increased marketing costs, and increase the increasing burden on the consumer in endures in the increasing share of marketing costs.
The main objective is estimating the marketing efficiency of the most important crops and agricultural commodities in Egypt represented in (wheat, maize, rice, lentils, faba bean, peanuts, tomatoes, onions, potatoes, zucchini, peas, garlic, cucumber, orange , bananas, grapes, mangoes, dates, red meat, poultry, fish, oils) during the period (1998-2013) using the functions specified methodology Farrell Approach, or data Envelopment analysis (DEA), according to the concepts of (CRS) Constant Returns to Scale and yield variable capacity Variable Returns to Scale (VRS) for estimating both the Technical Efficiency (TE), and Scale Efficiency (SE), and due to lack of data and information on production costs will be where uses two variables of Economic variables only, so as to estimate the efficiency and marketing are the marketing margin (marketing costs) which is the difference between the retail price and the price of the farm, as well as the retail price, which is derived from the farm and wholesale prices, and then affect the amount of margin marketing. The study also aims to study marketing margins, marketing and distribution of the scale of the product and wholesaler and retailer of pounds consumer to know the factors that lead to the lifting of the marketing efficiency, to achieve the objectives of both the producer and consumer

\section{Research results and discussion}

Estimating the marketing efficiency of the most important crops and agricultural commodities:

Was estimated marketing efficiency in two ways: one called Farrell Approach methodology, or the so-called (DEA) Data Envelopment Analysis, and the other is the traditional way, due to the lack of information on production costs, it will be using two variables of economic variables to estimate the competencies, the two marketing margin (marketing costs) which is the difference between the retail price and the price of the farm, as well as the retail price, as the retail price is derived from wholesale and farm prices, and thus affect the amount of marketing margin.

First: Estimating the marketing efficiency in a systematic way Farrell Approach, the (DEA) Data Envelopment Analysis:

\section{Field Crops Group:}

Was found by estimating the marketing efficiency, according to the model variable returns to scale Variable Returns to Scale, the marketing efficiency of the group of field crops, ranging from an upper limit stood at about $92.7 \%$, and a minimum was about $76.9 \%$ with an average of about $85.7 \%$, while the capacity efficiency Scale Efficiency about $83.5 \%$, and that group is suffering from a lack of marketing efficiency was about $14.3 \%$, and this is due to other factors not included in the model, and thus can increase the marketing efficiency of about $14.3 \%$ reduction in marketing margins used. It turns out that about $71.9 \%$ of the yields of scale in field crops group 
in the (irs) Increasing Return to Scale, and about $21.9 \%$ of the yield size (drs) Decreasing Return to Scale- table (1).

Wheat: show of results obtained in accordance with the model variable returns to scale, the marketing efficiency of the wheat crop was about $92.7 \%$, and thus can increase marketing efficiency by about $7.3 \%$ reduction in marketing margins used. It turns out that about $43.75 \%$ of the yield size in (irs) Increasing Return to Scale, and about $50 \%$ of the yield size (drs) Decreasing Return to Scale.

Corn: show of results obtained in accordance with the model variable returns to scale, the marketing efficiency of the corn crop was about $76.9 \%$, and thus can increase the marketing efficiency of about $23.1 \%$ reduction in marketing margins used. It turns out that about $93.75 \%$ of the yield size in increasing returns to scale (irs).

Rice: show of results obtained in accordance with the model variable returns to scale, the marketing efficiency of the rice crop was about $86.7 \%$, and thus can increase the marketing efficiency of about $13.3 \%$ reduction in marketing margins used. It turns out that about $93.75 \%$ of the yield size in increasing returns to scale (irs).

Lentils: Identification of the results obtained in accordance with the model variable returns to scale, the marketing efficiency of lentil amounted to about $86.2 \%$, and thus can increase the marketing efficiency of about $13.8 \%$ reduction in marketing margins, show that about $37.5 \%$ of the yield size in the increasing returns to scale (irs)., And about $56.25 \%$ of the yield size decreasing returns to scale (drs).

Faba bean: show of results obtained in accordance with the model variable returns to scale, the marketing efficiency of the faba bean crop amounted to about $80 \%$, and thus can increase the marketing efficiency of about $20 \%$ reduction in marketing margins used. It turns out that about $93.75 \%$ of the yield size in increasing returns to scale (irs)

Peanuts: show of results obtained in accordance with the model variable returns to scale, the marketing efficiency of the peanut crop was about $91.6 \%$, and thus can increase marketing efficiency by about $8.4 \%$ reduction in marketing margins used. It turns out that about $68.75 \%$ of the yield size in increasing returns to scale (irs), and about $25 \%$ of the yield size decreasing returns to scale (drs).

\section{Vegetable crops Group:}

Was found by estimating the marketing efficiency, according to the model variable returns to scale Variable Returns to Scale, the marketing efficiency of the group vegetable crops ranged from a higher limit was about $97.4 \%$, and a minimum was about $90.2 \%$ with an average of about $92.8 \%$, while the capacity efficiency Scale Efficiency about $88.1 \%$, and that group is suffering from a lack of marketing efficiency was about $7.2 \%$, and this is due to other factors not included in the model, and thus can increase marketing efficiency by about $7.2 \%$ reduction in marketing margins used. It turns out that about $63.4 \%$ of the yield of vegetable crops in the size range in the increasing returns to scale (irs), and about $21.4 \%$ of the yield size decreasing returns to scale (drs) - table (1).

Tomatoes: show of results obtained in accordance with the model variable returns to scale, the marketing efficiency of the tomato harvest amounted to about $93 \%$, and thus can increase marketing efficiency by about $7 \%$ reduction in marketing margins used. It turns out that about $93.7 \%$ percent of the yields of scale in increasing returns to scale (irs).

Onions: show of results obtained in accordance with the model variable returns to scale, the marketing efficiency of the onion crop amounted to about $93.2 \%$, and thus can increase marketing efficiency by about $6.8 \%$ reduction in marketing margins used. It turns out that about $93.75 \%$ of the yield size in increasing returns to scale (irs)

Potatoes: show of results obtained in accordance with the model variable returns to scale, the marketing efficiency of the potato crop was about $93.4 \%$, and thus can increase marketing efficiency by about $6.6 \%$ reduction in marketing margins used. It turns out that about $87.5 \%$ of the yields of scale in the increasing returns to scale (irs), and about $6.25 \%$ of the yield size decreasing returns to scale (drs).

Zucchini: show of results obtained in accordance with the model variable returns to scale, the marketing efficiency of the zucchini crop amounted to about $90.6 \%$, and thus can increase marketing efficiency by about $9.4 \%$ reduction in marketing margins used. It turns out that about $62.5 \%$ of the yields of scale in the increasing returns to scale (irs), and about $31.25 \%$ of the yield size decreasing returns to scale (drs).

Peas: show of results obtained in accordance with the model variable returns to scale, the marketing efficiency of the pea crop was about $90.2 \%$, and thus can increase marketing efficiency by about $9.8 \%$ reduction in marketing margins used. It turns out that about $62.5 \%$ of the yields of scale in the increasing stage returns to scale (irs), and about $31.25 \%$ of the yield size decreasing returns to scale (drs)

Garlic: show of results obtained in accordance with the model variable returns to scale, the marketing efficiency of the garlic harvest amounted to about $92 \%$, and thus can increase marketing efficiency by about $8 \%$ reduction in marketing margins used.

It turns out that about $43.75 \%$ of the yield size in increasing returns to scale (irs).

Cucumber: show of results obtained in accordance with the model variable returns to scale, the marketing efficiency of the crop cucumber amounted to about $97.4 \%$, and thus can increase marketing efficiency by about $2.6 \%$ reduction in marketing margins used. It turns out that about $81.25 \%$ of the yield size decreasing returns to scale (drs)

\section{Fruit Group:}

Was found by estimating the marketing efficiency, according to the model variable returns to scale Variable Returns to Scale, the marketing efficiency of the group fruit ranged between a maximum was about $93.6 \%$, and a minimum was about $86.6 \%$ with an average of about $90.4 \%$, while capacity efficiency Scale Efficiency amounted to about $83.9 \%$, and that group is suffering from a lack of efficiency in the marketing amounted to about $9.6 \%$, and this is due to other factors not included in the model, and thus can increase marketing efficiency by about $9.6 \%$ reduction in marketing margins used. It turns out that about $66.3 \%$ of the yield of fruit size in 
the group in the increasing returns to scale (irs), and about $16.3 \%$ of the yield size decreasing returns to scale (drs) - table (1)

Orange: show of results obtained in accordance with the model variable returns to scale, the marketing efficiency of the orange crop was about $93.6 \%$, and thus can increase marketing efficiency by about $6.4 \%$ reduction in marketing margins used. It turns out that about $93.75 \%$ of the yield size in increasing returns to scale (irs)

Bananas: show of results obtained in accordance with the model variable returns to scale, the marketing efficiency of the banana crop was about $89.8 \%$, and thus can increase the marketing efficiency of about $10.2 \%$ reduction in marketing margins used. It turns out that about $56.25 \%$ of the yield size in increasing returns to scale (irs), and about $37.5 \%$ of the yield size decreasing returns to scale (drs)

Grapes: show of results obtained in accordance with the model variable returns to scale, the marketing efficiency of the grape harvest amounted to about $92.3 \%$, and thus can increase marketing efficiency by about $7.7 \%$ reduction in marketing margins used. It turns out that about $68.75 \%$ of the yield size in increasing returns to scale (irs), and about $25 \%$ of the yield size decreasing returns to scale (drs).

Mango: show of results obtained in accordance with the model variable returns to scale, the marketing efficiency of the mango crop amounted to about $89.6 \%$, and thus can increase the marketing efficiency of about $10.4 \%$ reduction in marketing margins used. It turns out that about $87.5 \%$ of the yields of scale in the increasing returns to scale (irs).

Dates: show of results obtained in accordance with the model variable returns to scale, the marketing efficiency of cropDates amounted to about $86.6 \%$, and thus can increase the marketing efficiency of about $13.4 \%$ reduction in marketing margins used. It turns out that about $25 \%$ of the yield size in increasing returns to scale (irs), and about $18.75 \%$ of the yield size decreasing returns to scale (drs).

\section{Meat Group:}

Was found by estimating the marketing efficiency, according to the model variable returns to scale Variable Returns to Scale, the marketing efficiency of the Group of meat ranged between a maximum was about $87.6 \%$, and a minimum was about $81.2 \%$ with an average of about $83.7 \%$, while capacity efficiency Scale Efficiency amounted to about $74.4 \%$, and that group is suffering from a lack of marketing efficiency was about $16.3 \%$, and this is due to other factors not included in the model, and thus can increase the marketing efficiency of about $16.3 \%$ reduction in marketing margins used.

It turns out that about $89.6 \%$ of the yields of scale in the meat group in the increasing returns to scale (irs), and about $4.2 \%$ of the yield size decreasing returns to scale (drs) Table (1).

Red meat: show of results obtained in accordance with the model variable returns to scale, the marketing efficiency of red meat amounted to about $87.6 \%$, and thus can increase the marketing efficiency of about $12.5 \%$ reduction in marketing margins used. It turns out that about $93.75 \%$ of the yield size in increasing returns to scale (irs).
Poultry: show of results obtained in accordance with the model variable returns to scale, the marketing efficiency of poultry amounted to about $82.4 \%$, and thus can increase the marketing efficiency of about $17.6 \%$ reduction in marketing margins used. It turns out that about $93.75 \%$ of the yield size in increasing returns to scale (irs), and about $0 \%$ of the yield size decreasing returns to scale (drs).

Fish: show of results obtained in accordance with the model variable returns to scale, the marketing efficiency of fish amounted to about $81.2 \%$, and thus can increase the marketing efficiency of about $18.8 \%$ reduction in marketing margins used. It turns out that about $81.25 \%$ of the yield size in increasing returns to scale (irs), and about $12.5 \%$ of the yield size decreasing returns to scale (drs).

\section{Vegetable oils Group:}

Was found by estimating the marketing efficiency, according to the model variable returns to scale Variable Returns to Scale, the marketing efficiency of the group of vegetable oils ranged from a higher limit was about $100 \%$, and a minimum was about $20.7 \%$ with an average of about 77.1 , while capacity efficiency Scale Efficiency amounted to about $93.5 \%$, and that group is suffering from a lack of marketing efficiency was about $22.9 \%$, and this is due to other factors not included in the model, and thus can increase the marketing efficiency of about $22.9 \%$ reduction in marketing margins used. It turns out that about $6.25 \%$ of the yield size in the range of vegetable oils in the increasing returns to scale (irs), and about $87.5 \%$ of the yield size decreasing returns to scale (drs) - table (1).

Comparison of the estimated values of efficiency (DEA) method for crops and commodities during the period (1998-2013):

It was estimated Spearman correlation coefficient between the estimated values for efficiency compared to the results obtained by the values of Technical Efficiency (TE) by the Data Envelopment Analysis method (DEA), according to (CRS) Constant Return to Scale and Variable Return to Scale (VRS).

It was found from table (2) that the positive trend and significant correlation coefficients indicating the results agree, where he found a strong correlation between Constant Returns to Scale (CRS) and Variable Returns to Scale (VRS) with correlation coefficient was about 0.646.

\section{Second: Marketing Efficiency Using Standard Marketing Costs to Retail Price Ratio:}

Marketing costs account depends on marketing costs and production costs, as the minimization of marketing costs lead to maximize efficiency, and calculated marketing efficiency outside of dividing marketing costs (total marketing costs and production costs), has been replaced with (total marketing costs and production costs) retail price as a variable alternative, because it includes the product price and marketing margin.

Marketing costs for crops and agricultural commodities 1. Marketing costs for field crops: 
Field crops include those in the study (wheat, maize, rice, lentils, faba bean, peanut), and the average marketing cost ratio was about $34.7 \%$ in 1998 , then increased to about $37.6 \%$ in 2013 an increase of about $8.6 \%$, while average marketing costs ratio was about $34.3 \%$, based on the standard marketing costs which related to the retail price for a set of field crops during the average period (1998-2013) - Table (3).

\section{Marketing costs for vegetable crops:}

Vegetable crops include those in the study (tomatoes, onions, potatoes, zucchini, peas, garlic, cucumber), the average marketing cost ratio was about $57.3 \%$ in 1998, then increased to about $67.3 \%$ in 2013 an increase of about $17.5 \%$, while the average marketing cost ratio was about $62.5 \%$, based on the standard marketing costs which related to the retail price for a set of vegetable crops during the period (1998-2013)- Table (3)

\section{Marketing costs for fruit crops:}

Fruit crops include those in the study (oranges, bananas, grapes, mangoes, dates), and the average marketing cost ratio was about $43.2 \%$ in 1998 , then increased to about $54.3 \%$ in 2013 an increase of about $25.8 \%$, while the average rate marketing costs ratio of about $44.7 \%$, based on the standard marketing costs which related to the retail price for a set fruit crops during the average period (1998-2013).

\section{Marketing costs of the meat:}

Meat group include those in the study (red meat, poultry, fish), and the average marketing cost ratio reached about $17.04 \%$ in 1998, then it increased to about $19.8 \%$ in 2013 an increase of about $16.1 \%$, while the average marketing costs ratio stood at about $19.8 \%$, based on the standard marketing costs which related to the retail price of meat group average during the period (1998-2013) - Table (3).

5. Marketing costs for Vegetable Oils:

Vegetable oils include those in the study (cotton, sunflower, corn, soybean, palm), has an average marketing cost ratio was about $21 \%$ in 1998 , and then fell to about $13 \%$ in 2013, a decline of about $38 \%$, while Average marketing cost ratio was about $15.3 \%$, based on the standard marketing costs which related to the retail price for a set of vegetable oils during the average period (1998-2013) - Table (3).

Thirdly: the scale and marketing margins of the main crops and agricultural commodities in Egypt during the average period (1998-2013): shows the distribution of the scale of the marketing of the product and wholesaler and retailer of consumer pounds - Appendix (1).

(A) The product of pounds consumer share (\%): The average product per pound of about $65.7 \%$ Consumer, $37.5 \%$, $55.3 \%, 80.2 \%, 84.7 \%$ for field crops, vegetable crops, fruit crops, meat, and oils, respectively during the study period (1998-2013)

(B) The share of wholesaler of consumer pounds (\%): The average share wholesaler of pounds spent about $11.8 \%$ $.36 \%, 20.2 \%, 7.45 \%$, and $3.9 \%$ for field crops, vegetable crops, fruit crops, meat, and oils respectively.

(C) The retailer's share of the consumer pounds (\%): The average share retailer of consumer pounds, about $22.4 \%$,
$26.5 \%, 24.5 \%, 12.35 \%, 11.4 \%$ for field crops, vegetable crops, fruit crops, meat, and oils respectively.

(D) The share of the mediators of Consumer pounds (\%): The average share of the mediators of pounds spent about $34.3 \%, 62.5 \%, 44.7 \%, 19.8 \%, 15.3 \%$ for field crops, vegetable crops, fruit crops, meat, and oils, respectively.

Marketing Margins of the Main Crops and Agricultural Commodities in Egypt:

Marketing margin defined as the difference between the price paid by the final consumer, and the price received by the product, or is the difference between the retail price and farm price, calculated marketing margin in absolute image in units of cash, or in a comparative image which related to the selling price.

(A) marketing margin between the two phases of the wholesaler and the product: The total margin marketable absolute phases wholesaler and the product of about 0.4 , $1.08,0.93,1.95,0.27$ pounds for each of the field crops, vegetable crops, fruit crops, meat, and oils, respectively, during the study period (1998-2013). The marketing margin which related to phases wholesaler and the product of about $14.2 \%, 47.9 \%, 25.4 \%, 8.6 \%, 4.4 \%$ for field crops, vegetable crops, fruit crops, meat, and oils stood respectively during the study period (1998-2013).

(B) Marketing margin between the two phases of the retailer and wholesaler: The margin marketable absolute phases retailer and wholesaler, the average was $1.06,0.59,0.71$, 2.6, 0.72 pounds for each of the field crops, vegetable crops, fruit crops, meat, and oils respectively. The marketing margin which related to phases retailer and wholesaler, the average was $22.4 \%, 26.5 \%, 24.5 \%, 12.3 \%$, $11.4 \%$ for field crops, vegetable crops, fruit crops, meat, and oils, respectively.

(C) Marketing margin between the two phases of the retailer and the product: The total absolute marketing margin between the two phases of the retailer and the product of about 1.5, 1.7, 1.6, 4.5, 0.98 pounds for each of the field crops, vegetable crops, fruit crops, meat, and oils, respectively.

The marketing margin which related to phases retailer and producer of about $34.3 \%, 62.5 \%, 44.7 \%, 19.8 \%, 15.3 \%$ for field crops, vegetable crops, fruit crops, meat has reached, and oils with respectively - Appendix (1).

\section{Figures and Tables}

Table (2): Spearman correlation between the estimated efficiency coefficient values using the Data Envelopment analysis (DEA)

\begin{tabular}{c|c|c}
\hline $\begin{array}{c}\text { Variable Returns } \\
\text { To Scale (VRS) }\end{array}$ & $\begin{array}{c}\text { Constant Returns } \\
\text { To Scale (CRS) }\end{array}$ & \\
\hline & 1 & $\begin{array}{c}\text { Constant Returns To } \\
\text { Scale (CRS) }\end{array}$ \\
\hline 1 & $0.646^{* *}$ & $\begin{array}{c}\text { Variable Returns To } \\
\text { Scale (VRS) }\end{array}$ \\
\hline
\end{tabular}

Source: collected and calculated from table (1) .

$* *$ Significant at the 0.01 level of significance 
Proc. of The Third Intl. Conf. on Advances in Social Science, Management and Human Behaviour - SMHB 2015 Copyright ( $)$ Institute of Research Engineers and Doctors, USA .All rights reserved.

ISBN: 978-1-63248-067-5 doi: 10.15224/ 978-1-63248-067-5-103

Table (1) :Marketing Efficiency of the Most Important Crops and Agricultural Commodities in Egypt During the Period (1998-2013) Using Data Envelopment Analysis (DEA)

\begin{tabular}{|c|c|c|c|c|c|c|}
\hline Crop or Item & $\begin{array}{c}\text { Constant Returns } \\
\text { to Scale Crs* }\end{array}$ & $\begin{array}{c}\text { Variable Returns to } \\
\text { Scale Vrs** }\end{array}$ & Scale Efficiency*** & $\begin{array}{c}\text { lack Efficiency } \\
\text { accordance with Vrs }\end{array}$ & $\begin{array}{l}\text { Increasing return to } \\
\text { scale Efficiency irs }{ }^{* * * * *}\end{array}$ & $\begin{array}{l}\text { Decreasing return to } \\
\text { scale Efficiency drs }\end{array}$ \\
\hline \multicolumn{7}{|l|}{ Field Crops } \\
\hline Wheat & 0.874 & 0.927 & 0.939 & 7.3 & 43.8 & 50.0 \\
\hline maize & 0.664 & 0.769 & 0.838 & 23.1 & 93.8 & 0.0 \\
\hline Rice & 0.807 & 0.867 & 0.921 & 13.3 & 93.8 & 0.0 \\
\hline Lentils & 0.769 & 0.862 & 0.895 & 13.8 & 37.5 & 56.3 \\
\hline faba bean & 0.509 & 0.800 & 0.621 & 20.0 & 93.8 & 0.0 \\
\hline Peanuts & 0.739 & 0.916 & 0.796 & 8.4 & 68.8 & 25.0 \\
\hline Average & 0.727 & 0.857 & 0.835 & 14.3 & 71.9 & 21.9 \\
\hline \multicolumn{7}{|l|}{ Vegetable crops } \\
\hline Tomatoes & 0.807 & 0.930 & 0.870 & 7.0 & 93.8 & 0.0 \\
\hline Onions & 0.848 & 0.932 & 0.912 & 6.8 & 93.8 & 0.0 \\
\hline Potato & 0.613 & 0.934 & 0.661 & 6.6 & 87.5 & 6.3 \\
\hline Zucchini & 0.776 & 0.906 & 0.853 & 9.4 & 62.5 & 31.3 \\
\hline Peas & 0.822 & 0.902 & 0.918 & 9.8 & 62.5 & 31.3 \\
\hline Garlic & 0.892 & 0.920 & 0.971 & 8.0 & 43.8 & 0.0 \\
\hline cucumber & 0.958 & 0.974 & 0.984 & 2.6 & 0.0 & 81.3 \\
\hline Average & 0.817 & 0.928 & 0.881 & 7.2 & 63.4 & 21.4 \\
\hline \multicolumn{7}{|l|}{ Fruit crops } \\
\hline Orange & 0.732 & 0.936 & 0.783 & 6.4 & 93.8 & 0.0 \\
\hline Banana & 0.728 & 0.898 & 0.809 & 10.2 & 56.3 & 37.5 \\
\hline Grapes & 0.712 & 0.923 & 0.775 & 7.7 & 68.8 & 25.0 \\
\hline mangoes & 0.778 & 0.896 & 0.865 & 10.4 & 87.5 & 0.0 \\
\hline dates & 0.829 & 0.866 & 0.962 & 13.4 & 25.0 & 18.8 \\
\hline Average & 0.793 & 0.917 & 0.865 & 8.3 & 66.3 & 16.3 \\
\hline \multicolumn{7}{|l|}{ Meat } \\
\hline Red meat & 0.639 & 0.876 & 0.740 & 12.5 & 93.8 & 0.0 \\
\hline Poultry & 0.619 & 0.824 & 0.753 & 17.6 & 93.8 & 0.0 \\
\hline Fish & 0.586 & 0.812 & 0.738 & 18.8 & 81.3 & 12.5 \\
\hline Average & 0.615 & 0.837 & 0.744 & 16.3 & 89.6 & 4.2 \\
\hline vegetable oils & 0.721 & 0.771 & 0.935 & 22.9 & 6.3 & 87.5 \\
\hline Average Overall & 0.747 & 0.884 & 0.843 & 11.6 & & \\
\hline
\end{tabular}

Source: collected and calculated from reference (1) .
Crs* ${ }^{*}$ Constant Returns to Scale
Vrs** = Variable Returns to Scale
Scale $^{* * *}$ Efficiency $=$ Crs $/$ Vrs

Irs****= Increasing Returns to Scale

Appendix (1): Distribution share consumer pounds, and marketing margins of the main crops and agricultural commodities in Egypt during the period (1998-2013)

\begin{tabular}{|c|c|c|c|c|c|c|c|c|c|c|c|c|c|}
\hline \multirow[b]{2}{*}{ Kind } & \multicolumn{3}{|c|}{ prices (pound/ton) } & \multicolumn{4}{|c|}{ Consumer pound distribution ratio } & \multicolumn{2}{|c|}{$\begin{array}{c}\text { Product- } \\
\text { Wholesale }\end{array}$} & \multicolumn{2}{|c|}{ Retail- Wholesale } & \multicolumn{2}{|c|}{ Retail- Product } \\
\hline & Product $^{(1)}$ & Wholesale ${ }^{(2)}$ & Retail $^{(3)}$ & $\begin{array}{l}\text { Product } \\
\text { share }^{(4)}\end{array}$ & $\begin{array}{l}\text { Wholesale } \\
\text { r share }\end{array}$ & $\begin{array}{c}\text { retail } \\
\text { dealer } \\
\text { share }{ }^{(6)}\end{array}$ & $\begin{array}{l}\text { Brokers } \\
\text { share }^{(7)}\end{array}$ & Absolute & $\%$ & Absolute & $\%$ & Absolute & $\%$ \\
\hline Wheat & 1.32 & 1.54 & 2.02 & 64.9 & 11.44 & 23.66 & 35.1 & 0.22 & 14.12 & 0.48 & 23.66 & 0.71 & 35.1 \\
\hline maize & 1.22 & 1.26 & 1.67 & 71.18 & 4.04 & 24.78 & 28.82 & 0.04 & 5.42 & 0.41 & 24.78 & 0.45 & 28.82 \\
\hline Rice & 1.28 & 1.77 & 2.49 & 53.23 & 25.46 & 21.31 & 46.77 & 0.49 & 27.29 & 0.72 & 21.31 & 1.21 & 46.77 \\
\hline Lentils & 4.1 & 4.67 & 5.78 & 67.1 & 12.99 & 19.91 & 32.9 & 0.57 & 16.3 & 1.11 & 19.91 & 1.68 & 32.9 \\
\hline faba bean & 2.89 & 3.4 & 4 & 76.11 & 9.84 & 14.05 & 23.89 & 0.51 & 11.71 & 0.6 & 14.05 & 1.11 & 23.89 \\
\hline Peanuts & 4.94 & 5.53 & 8.53 & 61.85 & 7.29 & 30.86 & 38.15 & 0.58 & 10.56 & 3.01 & 30.86 & 3.59 & 38.15 \\
\hline Field Crops & & & & 65.73 & 11.84 & 22.43 & 34.27 & 0.40 & 14.23 & 1.06 & 22.43 & 1.46 & 34.27 \\
\hline Tomatoes & 0.74 & 1.3 & 1.83 & 43.09 & 25.85 & 31.06 & 56.91 & 0.56 & 36.78 & 0.53 & 31.06 & 1.09 & 56.91 \\
\hline Onions & 0.49 & 1.32 & 1.83 & 30.91 & 39.68 & 29.41 & 69.09 & 0.83 & 55.66 & 0.5 & 29.41 & 1.33 & 69.09 \\
\hline Potato & 0.9 & 1.69 & 2.18 & 50.94 & 24.83 & 24.23 & 49.06 & 0.79 & 31.83 & 0.49 & 24.23 & 1.28 & 49.06 \\
\hline Zucchini & 0.85 & 1.41 & 2.03 & 42.72 & 27.89 & 29.4 & 57.28 & 0.57 & 39.9 & 0.61 & 29.4 & 1.18 & 57.28 \\
\hline Peas & 1.09 & 1.93 & 2.67 & 40.98 & 30.85 & 28.18 & 59.02 & 0.84 & 40.77 & 0.74 & 28.18 & 1.58 & 59.02 \\
\hline Garlic & 1.05 & 4.06 & 4.96 & 22.94 & 55.59 & 21.47 & 77.06 & 3.01 & 70.48 & 0.9 & 21.47 & 3.91 & 77.06 \\
\hline cucumber & 0.62 & 1.57 & 1.94 & 31.09 & 47.04 & 21.88 & 68.91 & 0.95 & 60.12 & 0.37 & 21.88 & 1.32 & 68.91 \\
\hline Vegetable crops & & & & 37.52 & 35.96 & 26.52 & 62.48 & 1.08 & 47.93 & 0.59 & 26.52 & 1.67 & 62.48 \\
\hline Orange & 0.93 & 1.29 & 1.81 & 55.25 & 14.57 & 30.17 & 44.75 & 0.36 & 19.6 & 0.52 & 30.17 & 0.89 & 44.75 \\
\hline Banana & 1.81 & 2.22 & 2.92 & 63.59 & 11.7 & 24.7 & 36.41 & 0.41 & 13.98 & 0.7 & 24.7 & 1.11 & 36.41 \\
\hline Grapes & 1.87 & 2.89 & 3.68 & 54.44 & 23.59 & 21.97 & 45.56 & 1.02 & 30.26 & 0.79 & 21.97 & 1.81 & 45.56 \\
\hline mangoes & 2.82 & 5.41 & 6.29 & 46.43 & 37.98 & 15.59 & 53.57 & 2.59 & 44.45 & 0.88 & 15.59 & 3.47 & 53.57 \\
\hline dates & 1.25 & 1.51 & 2.17 & 56.64 & 13.18 & 30.18 & 43.36 & 0.26 & 18.53 & 0.66 & 30.18 & 0.92 & 43.36 \\
\hline Fruit crops & & & & 55.27 & 20.20 & 24.52 & 44.73 & 0.93 & 25.36 & 0.71 & 24.52 & 1.64 & 44.73 \\
\hline Red meat & 23.66 & 28.1 & 33.15 & 73.81 & 11.61 & 14.57 & 26.19 & 4.44 & 13.6 & 5.05 & 14.57 & 9.48 & 26.19 \\
\hline Poultry & 9.12 & 9.92 & 11.36 & 81.37 & 5.83 & 12.79 & 18.63 & 0.8 & 6.71 & 1.44 & 12.79 & 2.24 & 18.63 \\
\hline Fish & 10.94 & 11.56 & 12.79 & 85.38 & 4.92 & 9.7 & 14.62 & 0.62 & 5.43 & 1.24 & 9.7 & 1.85 & 14.62 \\
\hline Meat & & & & 80.19 & 7.45 & 12.35 & 19.81 & 1.95 & 8.58 & 2.58 & 12.35 & 4.52 & 19.81 \\
\hline vegetable oils & 5.92 & 6.18 & 6.9 & 84.7 & 3.93 & 11.37 & 15.3 & 0.27 & 4.43 & 0.72 & 11.37 & 0.98 & 15.3 \\
\hline
\end{tabular}

Source: collected and calculated from data: Central Agency for Public Mobilization and Statistics.

Product share $^{(4)}=(1) /(3) * 100$

Retail dealer share ${ }^{(6)}=((3)-(2)) / 3 * 100$
Wholesaler share ${ }^{(5)}=((2)-(1)) / 3 * 100$

Brokers share $^{(7)}=(6)+(5)$ 
Proc. of The Third Intl. Conf. on Advances in Social Science, Management and Human Behaviour - SMHB 2015 Copyright (c) Institute of Research Engineers and Doctors, USA .All rights reserved.

ISBN: 978-1-63248-067-5 doi: 10.15224/ 978-1-63248-067-5-103

Table(3): Marketing Efficiency of the most important crops and agricultural commodities in Egypt during the period (1998-2013) by using standard marketing costs to retail price ratio.

\begin{tabular}{|c|c|c|c|c|c|}
\hline & $\begin{array}{c}\text { Field } \\
\text { Crops }\end{array}$ & $\begin{array}{c}\text { Vegetable } \\
\text { crops }\end{array}$ & $\begin{array}{c}\text { Fruit } \\
\text { crops }\end{array}$ & $\begin{array}{c}\text { vegetable } \\
\text { oils }\end{array}$ & Meat \\
\hline $\mathbf{1 9 9 8}$ & 34.66 & 57.32 & 43.17 & 17.04 & 21.03 \\
\hline $\mathbf{1 9 9 9}$ & 35.13 & 56.64 & 47.84 & 17.98 & 19.39 \\
\hline $\mathbf{2 0 0 0}$ & 38.04 & 53.62 & 47.45 & 18.12 & 17.93 \\
\hline $\mathbf{2 0 0 1}$ & 37.11 & 62.73 & 41.94 & 20.70 & 17.66 \\
\hline $\mathbf{2 0 0 2}$ & 38.04 & 63.02 & 42.31 & 23.83 & 17.59 \\
\hline $\mathbf{2 0 0 3}$ & 31.75 & 65.75 & 40.61 & 20.35 & 16.57 \\
\hline $\mathbf{2 0 0 4}$ & 36.74 & 67.61 & 42.55 & 16.21 & 16.91 \\
\hline $\mathbf{2 0 0 5}$ & 28.89 & 62.42 & 42.25 & 12.78 & 20.61 \\
\hline $\mathbf{2 0 0 6}$ & 32.63 & 58.00 & 32.07 & 17.57 & 10.88 \\
\hline $\mathbf{2 0 0 7}$ & 30.84 & 56.68 & 33.62 & 18.04 & 3.92 \\
\hline $\mathbf{2 0 0 8}$ & 40.26 & 61.26 & 51.19 & 18.63 & 12.37 \\
\hline $\mathbf{2 0 0 9}$ & 31.86 & 61.93 & 46.06 & 18.09 & 13.26 \\
\hline $\mathbf{2 0 1 0}$ & 28.47 & 66.96 & 52.28 & 26.32 & 13.63 \\
\hline $\mathbf{2 0 1 1}$ & 32.96 & 68.88 & 49.34 & 27.65 & 16.09 \\
\hline $\mathbf{2 0 1 2}$ & 33.32 & 69.47 & 48.64 & 23.92 & 13.91 \\
\hline $\mathbf{2 0 1 3}$ & 37.63 & 67.34 & 54.33 & 19.79 & 13.03 \\
\hline Average & $\mathbf{3 4 . 3}$ & $\mathbf{6 2 . 5}$ & $\mathbf{4 4 . 7}$ & $\mathbf{1 9 . 8}$ & $\mathbf{1 5 . 3}$ \\
\hline b & $\mathbf{- 0 . 3 9 3}$ & $\mathbf{0 . 6 7 0}$ & $\mathbf{0 . 7 1 2}$ & $\mathbf{0 . 5 0 1}$ & $\mathbf{- 0 . 5 1 1}$ \\
\hline Growth & $\mathbf{- 1 . 1 5}$ & $\mathbf{1 . 0 7}$ & $\mathbf{1 . 5 9}$ & $\mathbf{2 . 5 3}$ & $\mathbf{- 3 . 3 4}$ \\
\hline R & $\mathbf{0 . 2 6}$ & $\mathbf{0 . 4 1 8}$ & $\mathbf{0 . 2 4 6}$ & $\mathbf{0 . 3 1 3}$ & $\mathbf{0 . 3 2 7}$ \\
\hline F & $\mathbf{4 . 9 1}{ }^{*}$ & $\mathbf{1 0 . 0 4}$ & $\mathbf{4 . 5 8}$ & $\mathbf{6 . 3 7}$ & $\mathbf{6 . *} *$ \\
\hline
\end{tabular}

Source: collected and calculated from reference (1)

* Significant at the 0.01 . ** Significant at the 0.05 level of significance

\section{Conclusion}

This study is based on analysis method of statistical descriptive and quantitative, with the use of some analytical statistical methods such as the analysis of time series, simple and annual rates of growth and decline, as were some of the technical efficiency of marketing for the most important crops and agricultural commodities in Egypt indicators estimate, methodology Farrell Approach, or what called the (DEA) Data Envelopment Analysis and learn about the services and functions of marketing through the s of various marketing and tract, and to identify the product's share and the share of the wholesaler, and the share of the retailer, from the distribution of pounds consumer, to judge the efficiency of the performance of the system catalog, and the study of marketing margins to get to know marketing differences, and the factors influencing them to identify the most important marketing problems, knowledge of the factors that lead to the lifting of the marketing efficiency, to achieve the goals of both the producer and the consumer using the border specific methodology The Deterministic Frontier Approach using the Data Envelopment Analysis (DEA), according to the concepts of ( CRS) Constant Returns to Scale and Variable Returns to Scale (VRS) for estimating both the Technical Efficiency (TE), and Scale Efficiency (SE)

\section{References}

[1] Website of the Central Agency for Public Mobilization and Statistics www.capmas.gov.eg

[2] Jaber Bassiouni, Abdul Hafiz Saeed - the marketing efficiency of fish for some fish species in the Arab Republic of Egypt, Mansoura University Journal of Agricultural Sciences, Vol. 26, No. 2, February 2001.

[3] Jaber Ahmed Bassiouni, Mamdouh El-Badry - marketing efficiency of the most important grain crops in the Arab Republic of Egypt, the Fourth International Conference Thirty of Statistics and Computer Science and its applications, the Egyptian Statistical Association and the Central Agency for Public Mobilization and Statistics, 5 to 16 April 2009.

[4] Mahmoud Hanafi, Mamdouh El-Badry - "Measuring the efficiency of macro-economy of the Nile Basin countries using the methodology border Stochastic Frontier Approach (SFA)", the Sixth International Conference Thirty of Statistics and Computer Science and its applications, the Egyptian Statistical Association and the Central Agency for Public Mobilization and Statistics, from 11 - April 22, 2011.

[5] Coelli, T.J .A Guide to Frontier Version 4.1: A Computer Program for Stochastic Frontier production and Cost Function Estimation, Mimeo Department of Econometrics, University of New England, Armidale, 1995.

[6] Farrel, Measuring the Technical Efficiency of Company, Ed., Activity of Production and Allocation, Cowles Commission for Research in Economics, Monograph No 13, Wiley, New York, 1957.

[7] Johnston, J., Econometric Methods, 3rd, McGraw-Hill Book Company, New York, 1984.

[8] Lovel, C.A.K . Production Frontier and Productive Efficiency , in Fried, H. O., C.A.K Lovell and S.S Schmidt (Eds), The Measurement of Productive Efficiency, Oxford University Press, New York, 3- 67, 1993

About Author (s):

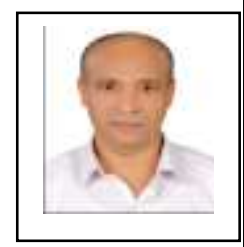

Mamdouh Elbadry was born in Alexandria in 1969. He got his B.Sc. in 1992 at Faculty of agriculture, Alexandria University, and got his M.SC in 1998 and $\mathrm{Ph}$. D. in 2009 at the agriculture Alexandria University. He worked as a Specialist (1995-2011), Research Assistant (2011) in Agricultural Economics Research Institute, Agricultural Research Centre, Egypt, and Researcher (Doctor) (2011-until now). He is a membership of Egyptian Association of Agricultural Economics (Cairo, Egypt). He published many searches in field study and participated in many local and international conferences

Samir Basilious Nakhla was born in Cairo in 1957. He got his B.Sc. in 1983 at Faculty of agriculture Cairo University, and got his M.SC in 1998 and $\mathrm{Ph}$. D. in 2005 at the agriculture Alexandria University. $\mathrm{He}$ worked as a Researcher Assistant (2009) in Agricultural Economics Research Institute, Agricultural Research Centre, Egypt, and Researcher (Doctor) (2009-until now). He is a membership of Egyptian Association of Agricultural Economics (Cairo, Egypt). He published many searches in field study and participated in many local and international conferences

Nouran El Hamid Ibrahim Abd El Gawwad: was born in Mansoura in 1985. She is a lecturer in Faculty of Agricultural, Mansoura University. She got her B.Sc. in 2005 department of Agricultural Economic at Faculty of Agricultural, Mansoura University, and got her M.SC in 2009 and Ph. D. in 2013. She is a membership of Egyptian Association of Agricultural Economics (Cairo, Egypt).

She published many researches in Agricultural Economic and participated in many local and international conferences. 